Aim of the study: To study the mechanisms of inhibition of cell growth and induction of DNA damage in oridonintreated MCF-7 human breast cancer cells.

Material and methods: The cytotoxicity of oridonin-treated MCF-7 cells was measured by MTT assay. Cell cycle phase distribution was analyzed by flow cytometry. P-ATM, P-CHK2, $\gamma \mathrm{H} 2 \mathrm{AX}$ and $\mathrm{P}$-P53 protein expressions were detected by Western blot analysis. The expression of r-h2ax and P-ATM was also detected by immunofluorescence staining. The degree of cellular damage of oridonin-induced MCF-7 human breast cancer cells was confirmed by the comet assay analysis of DNA fragmentation. Results: Oridonin inhibited cell growth in a time- and dose-dependent manner. The IC50 values at 48 and 72 hours were 78.3 and $31.62 \mu \mathrm{mol} / \mathrm{l}$, respectively. Oridonin induced $\mathrm{G} 2 / \mathrm{M}$ phase arrest in MCF-7 cells. MCF-7 cells treated with oridonin showed significant DNA damage as shown by an increase in olive tail moment (OTM). The protein expression levels of P-ATM, P-CHK2, $\gamma \mathrm{H} 2 \mathrm{AX}$ and P-P53 were increased significantly in a dose-dependent manner.

Conclusions: DNA damage provokes p53-mediated G2/M cell cycle arrest in oridonin-induced MCF-7 cells through the mechanism of CHK2 activation by activated ATM protein kinase, which is induced by oridonin.

Key words: oridonin, ATM, CHK2, cell cycle, p53, apoptosis.

\section{DNA damage induced by oridonin involves cell cycle arrest at G2/M phase in human MCF-7 cells}

\author{
Tao Zhang ${ }^{1,2}$, Yan Tan ${ }^{13}$, Rui Zhao ${ }^{4}$, Zhaoyang Liu ${ }^{5}$
}

${ }^{1}$ Central Research Laboratory, the First Affiliated Hospital of Jilin University, Changchun, China

2School of Basic Medical Sciences, Jiamusi University, No. 148 Xuefu Street, Jiamusi City, Heilongjiang Province, China

3People's Hospital of Jilin Province Tumor Biological Treatment Research Center Changchun, China

4Department of Pharmaceutical Engineering, College of Life Science and Biotechnology, Heilongjiang August First Land Reclamation University, Daqing High-Tech Industrial Development Zone, China

${ }^{5}$ The First Affiliated Hospital, Jiamusi University, Jiamusi City, Heilongjiang Province, China

\section{Introduction}

Breast cancer is a leading cause of morbidity and mortality in women, in both developed and developing countries [1]. Chemotherapy is the most common treatment for cancer. Unfortunately, many of the chemotherapeutic drugs are non-specific and cause severe side effects. Therefore, searching for new alternative strategies for the prevention and treatment of breast cancer is essential. Natural products, including plants, microorganisms and marines, have been considered as valuable sources for anticancer drug discovery [2]. Oridonin is extracted and purified from a traditional Chinese herb, Rabdosia rubescens, a member of the salvia family. Oridonin (Fig. 1) has various biological, pharmaceutical, and physiological properties and functions [3, 4]. Oridonin has been studied extensively in China and has been shown to possess anti-tumor activity against murine sarcoma and leukemia cells [5]. It has been reported that oridonin was found to induce growth inhibition and apoptosis of the human breast cancer cell line MCF-7 [6]. However, a systematic analysis of the mechanisms of oridonin's anti-tumor activity in MCF-7 has not been undertaken.

The DNA damage response (DDR), caused by a variety of stimuli, arrests the cell cycle to allow damage repair or direct cell apoptosis. An imbalance between DNA damage and DNA repair activities may affect cell viability. After DNA damage, the cell cycle is arrested at the transition from the G1 to $S$ phase or from the $G 2$ to $M$ phase of the cell cycle. Increasing evidence indicates a central role for $p 53$ in mediating cell cycle arrest or apoptosis [7]. One of the early events initiated by double-stranded DNA breaks (DSBS) is the phosphorylation of serine 139 in the SQE motif located on the tail of histone $\mathrm{H} 2 \mathrm{AX}(\gamma \mathrm{H} 2 \mathrm{AX})$ by ATM/ATR kinases and the subsequent rapid formation of $\gamma \mathrm{H} 2 \mathrm{AX}$ foci at the DSB sites [8]. These foci are essential in facilitating the assembly of repair factors on damaged DNA sites and also aid in the activation of DNA damage checkpoints [9]. The loss or reduction of H2AX could facilitate tumorigenesis [10]. Taken together, a large body of evidence demonstrates that $\gamma \mathrm{H} 2 \mathrm{AX}$ foci play an essential role in the cellular DNA damage response. In addition, to facilitate the formation of $\gamma \mathrm{H} 2 \mathrm{AX}$ nuclear foci, ataxia-telangiectasia mutated (ATM) also induces cell cycle arrest through phosphorylation of its targets, p53 and CHK2 [11]. CHK2 then phosphorylates CDC25C on serine 216 (S216), which prevents CDC25C from dephosphorylating tyrosine 15 and threonine 14 of CDC2 
(or CDK1), resulting in cell cycle arrest at the G2 phase [12]. In the present study, we demonstrated that activated p53 contributed to oridonin-induced cell cycle arrest in human breast MCF-7 cells, and we further investigated the mechanisms of cell growth inhibition and DNA damage repair in oridonin-treated MCF-7 human breast cancer cell.

\section{Material and methods}

\section{Material}

Oridonin was obtained from Sigma (St. Louis, MO, USA). Fetal bovine serum (FBS) was purchased from TBD Biotechnology Development (Tianjin, China); Thiazolyl blue (MTT) was from Sino-American Biotechnology (Beijing, China); polyclonal antibodies against r-h2ax, phosphorylated ATM, phosphorylated CHK2 and phosphorylated P53, horseradish peroxidase-conjugated secondary antibody (goat-antirabbit or goat-anti-mouse) were purchased from Santa Cruz Biotechnology (Santa Cruz, CA, USA).

\section{Cell lines and cell culture}

The human breast cancer MCF-7 cell line was obtained from American Type Culture Collection (ATCC, Rockville, MD, USA). The cells were cultured in RPMI 1640 medium (GIBCO, Gaithersburg, MD, USA) supplemented with $10 \%$ fetal bovine serum (FBS) and 0.03\% L-glutamine (GIBCO, Gaithersburg, MD, USA) and maintained at $37^{\circ} \mathrm{C}$ with $5 \% \mathrm{CO}_{2}$ in a humidified atmosphere.

\section{Cell growth inhibition assay}

The cytotoxic effect of oridonin on human breast cancer MCF-7 cells was measured by MTT assay. MCF-7 cells were cultured in RPMI 1640 medium containing 10\% FBS incubated with oridonin at the concentrations of $0,10,20,40,80$, $160 \mu \mathrm{mol} / \mathrm{l}$. After treatment with different concentrations of oridonin for 24, 48 and 72 hours, MTT was added to each well at a final concentration of $0.4 \mathrm{mg} / \mathrm{ml}$ and further incubated for $3 \mathrm{~h}$ at $37^{\circ} \mathrm{C}$. The MTT solution in medium was then removed. To solubilize formazan crystals formed in viable cells, $100 \mu$ l of dimethyl sulfoxide (DMSO) was added to each well before the absorbance at $492 \mathrm{~nm}$ was measured using a microplate ELISA reader (Model 550, Bio-Rad, USA). The IC50 value was expressed as the concentration of oridonin that inhibited the growth of cells by 50\%. IC50 values of each sample were collected from three replicates. The mean and standard deviations were calculated from the value of the three replicates. Values for the IC50 assay were obtained.

\section{Measurement of DNA damage by the comet assay}

Oridonin-induced DNA damage was determined using the comet assay. Cells were treated with oridonin (80 and $160 \mu \mathrm{mol} / \mathrm{l})$ for 48 hours in complete medium, and the comet assay procedure in this study was a modification of the method described earlier [13]. Briefly, after treatment with oridonin, the cells were harvested and resuspended in icecold PBS. Approximately $1 \times 10^{4}$ cells in a volume of $100 \mu \mathrm{l}$ of $0.5 \%$ (w/v) low melting point agarose were pipetted onto frosted microscope slides and allowed to solidify under a coverslip, which was then carefully removed. The slides were

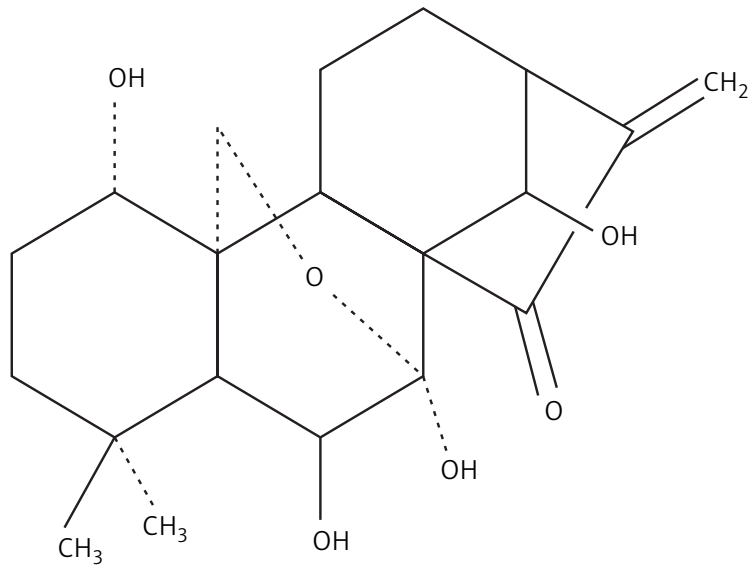

Fig. 1. Chemical structure of oridonin

immersed in ice-cold lysis solution containing $2.5 \mathrm{~mol} / \mathrm{l} \mathrm{NaCl}$, $10 \mathrm{mmol} / \mathrm{I}$ Tris, $100 \mathrm{mmol} / \mathrm{l} \mathrm{Na} \mathrm{Na}_{2}$-EDTA, and 1\% (w/v) N-lauroylsarcosine, adjusted to $\mathrm{pH} 10.0$, with $1.0 \%$ Triton $\mathrm{X}-100$ added immediately before use. After 2 hours at $4^{\circ} \mathrm{C}$, the slides were removed from the lysis solution, drained, and placed in a horizontal gel electrophoresis tank filled with buffer [0.3 mol// NaOH, $1 \mathrm{mmol} / \mathrm{IEDTA}(\mathrm{pH}$ 13)] and subjected to electrophoresis for 20 minutes at $300 \mathrm{~mA}$. Slides were transferred to neutralization solution (0.4 mol/l Tris- $\mathrm{HCl}, \mathrm{pH} 7.5)$ for 3-5 minutes, washed and stained with $75 \mu$ lethidium bromide $(20 \mu \mathrm{g} / \mathrm{ml})$ for 5 minutes. After a final wash in doubledistilled water, the gels were covered with glass cover slips. Slides were viewed using a fluorescence microscope (Olympus BX60F-3, Olympus Optical, Japan). The image analysis software (CASP, Poland) provides a full range of densitometric and geometric parameters describing the complete comet, as well as the head and tail portions. For each sample, the tail lengths (in micrometers) of a minimum of 50 comets were analyzed. The length of the comet was quantified as the distance from the center of the cell nucleus to the tip of the tail in pixel units. The tail moment, expressed in arbitrary units, was calculated by multiplying the percent of DNA (fluorescence) in the tail by the length of the tail.

\section{Cell cycle analysis}

Cell cycle analysis was carried out by FACScan flow cytometer using a standard protocol. Briefly, MCF-7 cells were harvested by centrifugation, washed with PBS, and fixed with cold $70 \%$ ethanol overnight. The fixed cells were then stained with PI solution consisting of $50 \mu \mathrm{g} / \mathrm{ml} \mathrm{PI}, 20 \mu \mathrm{g} / \mathrm{ml}$ RNase $\mathrm{A}$ and $0.1 \%$ Triton $\mathrm{X}-100$. After $1 \mathrm{~h}$ incubation in the dark, fluorescence-activated cells were sorted in a FACScan flow cytometer. The distribution of cells in the different cellcycle phases was analyzed using Multicycle software (Phoenix Flow Systems, San Diego, CA). The percentage of cells in each phase of the cell cycle was determined at least in triplicate and expressed as mean \pm SD.

\section{Immunofluorescence staining}

Cells were treated as defined in the figure legends. Immunofluorescent staining was carried out by fixing cells 
Table 1. Effect of oridonin on inhibition rate of MCF-7 cells

\begin{tabular}{|lccc}
\hline Oridonin $(\mu \mathrm{mol} / \mathrm{l})$ & \multicolumn{3}{c}{ Inhibition rate $(\%)$} \\
\cline { 2 - 4 } & 24 hours & 48 hours & 72 hours \\
\hline 0 & 0 & 0 & 0 \\
\hline 20 & $5.1 \pm 0.1$ & $8.4 \pm 0.3$ & $12.1 \pm 0.5$ \\
\hline 40 & $17.5 \pm 0.3$ & $21.8 \pm 1.1^{\star}$ & $31.6 \pm 1.7^{\star}$ \\
\hline 80 & $22.4 \pm 1.5^{*}$ & $37.9 \pm 2.3^{*}$ & $57.8 \pm 2.7^{\star}$ \\
\hline 160 & $35.8 \pm 2.1^{*}$ & $51.7 \pm 2.8^{*}$ & $68.9 \pm 3.3^{*}$ \\
\hline
\end{tabular}

${ }^{*} P<0.05$, compared with control

with pre-chilled $\left(-20^{\circ} \mathrm{C}\right)$ acetone-methanol for $15 \mathrm{~min}$. The primary antibodies, anti- $\gamma \mathrm{H} 2 \mathrm{AX}$ (Upstate, $0.5 \mathrm{\mu g} / \mathrm{ml}$ ) and antiphospho-ATM (S1981) (Cell Signaling, $1: 100)$, were then added to the slides at $4^{\circ} \mathrm{C}$ overnight. After washing, secondary antibodies, FITC-Donkey anti-rabbit IgG (1 : 200, Jackson Immuno Research Lab) and Rhodamine-Donkey anti-mouse IgG (1 : 200, Jackson Immuno Research Lab) were applied for $1 \mathrm{~h}$ at room temperature. The slide was then covered with VECTASHIELD mounting medium with DAPI (VECTOR Lab Inc., Burlingame, CA94010). Images were taken with a fluorescent microscope (Carl Zeiss, Axiovert 200).

\section{Cell lysis and Western blot}

Cells were lysed in a buffer containing $20 \mathrm{mM}$ Tris (pH 7.4), $150 \mathrm{mM} \mathrm{NaCl}, 1 \mathrm{mM}$ EDTA, $1 \mathrm{mM}$ EGTA, 1\% Triton X-100, $25 \mathrm{mM}$ sodium pyrophosphate, $1 \mathrm{mM} \mathrm{NaF}, 1 \mathrm{mM} \beta$-glycerophosphate, $0.1 \mathrm{mM}$ sodium orthovanadate, $1 \mathrm{mM}$ PMSF,

Table 2. Effect of oridonin on DNA damage

\begin{tabular}{lccc|}
\hline Groups & $\begin{array}{c}\text { Percent of cells } \\
\text { with tails }(\%)\end{array}$ & Tail length $(\mu \mathrm{m})$ & Tail moment \\
\hline $\begin{array}{l}\text { control } \\
7.15 \pm 1.04\end{array}$ & $8.71 \pm 1.18$ & $1.62 \pm 0.53$ \\
\hline $\begin{array}{l}\text { oridonin } 80 \\
(\mu \mathrm{mol} / \mathrm{l})\end{array}$ & $49.25 \pm 2.76^{*}$ & $29.38 \pm 1.37^{*}$ & $5.72 \pm 1.84^{*}$ \\
\hline $\begin{array}{l}\text { oridonin } 160 \\
(\mu \mathrm{mol} / \mathrm{l})\end{array}$ & $73.53 \pm 3.16^{* *}$ & $60.42 \pm 3.25^{* *}$ & $15.76 \pm 0.87^{* *}$ \\
\hline
\end{tabular}

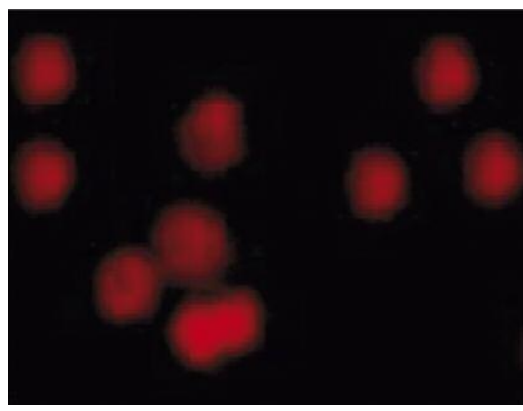

control

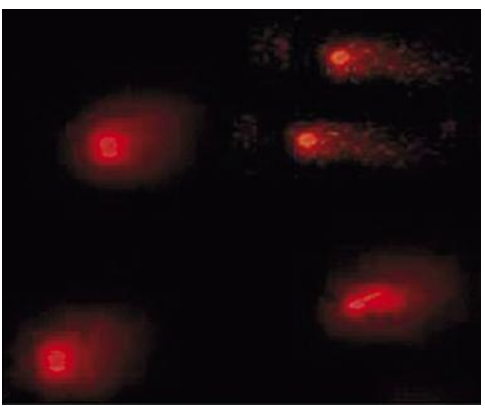

oridonin $(80 \mu \mathrm{mol} / \mathrm{l})$
$2 \mu \mathrm{g} / \mathrm{ml}$ leupeptin and $10 \mu \mathrm{g} / \mathrm{ml}$ aprotinin. Fifty $\mu \mathrm{g}$ of total cell lysate was separated on SDS-PAGE gel and transferred onto Immobilon-P membranes (Millipore). Membranes were blocked with 5\% skim milk and then incubated with the indicated antibodies at room temperature for $1 \mathrm{~h}$. Signals were detected using an ECL Western Blotting Kit (Amersham). Primary antibodies and concentrations used were: anti-phospho-p53(S15) (Cell Signaling, 1 : 1000); anti- $\gamma \mathrm{H} 2 \mathrm{AX}(1$ : 1000, Upstate), anti-phospho-ATM (S1981) (Rockland, 1 : 500), anti-CHK2 (Cell Signaling, $1: 1000$ ) and anti-actin (Santa Cruz, $1: 1000)$.

\section{Statistical analysis}

All the grouped data were statistically evaluated with SPSS/13.0 software. Statistical analysis was performed by one-way analysis of variance (ANOVA). P-values of less than 0.05 were considered to be significant. All the results were expressed as the mean \pm SD.

\section{Results}

\section{Cytotoxicity of oridonin on MCF-7 cells}

Oridonin induced MCF-7 cell death in a time- and dosedependent manner. Oridonin from 20 to 160 mmol/I showed inhibitory effects on MCF-7 cell growth. By $48 \mathrm{~h}$ after $80 \mu \mathrm{mol} / \mathrm{l}$ oridonin treatment, the cell death rate reached almost 50\% (Table 1). The IC50 value of MCF-7 cells, treated with oridonin for $48 \mathrm{~h}$, was $78.3 \mu \mathrm{mol} / \mathrm{l}$. Therefore, $48 \mathrm{~h}$ incubation with oridonin appears sufficient for the half induction of cell death.

\section{Effect of oridonin on DNA damage}

We determined the effect of oridonin on cellular DNA damage using the comet assay, which was used as a biomarker of apoptosis. As shown in Fig. 2 and Table 2, treatment of MCF-7 cells with oridonin (80 and $160 \mu \mathrm{mol} / \mathrm{l})$ for 48 hours resulted in significant DNA damage $(p<0.01)$ compared with cells that were not treated with oridonin. The DNA damaging effect in terms of DNA fragmentation was determined by measuring the tail length and tail moment of the comet under a microscope and casp software. The data represented at least 50 DNA-damaged cells in each treatment group. Mean comet tail moment was based on analysis of 100 comet images per slide after treatment with various concentrations of oridonin.

Fig. 2. Effect of oridonin on DNA damage. DNA damage as detected using an alkaline comet assay $48 \mathrm{~h}$ after oridonin treatment in MCF-7 cells. Photomicrographs of damaged DNA after the various oridonin treatments showing an increase in the tail length and tail moment 


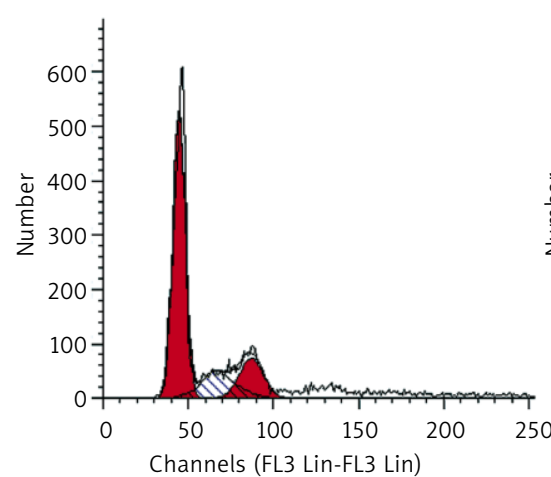

control

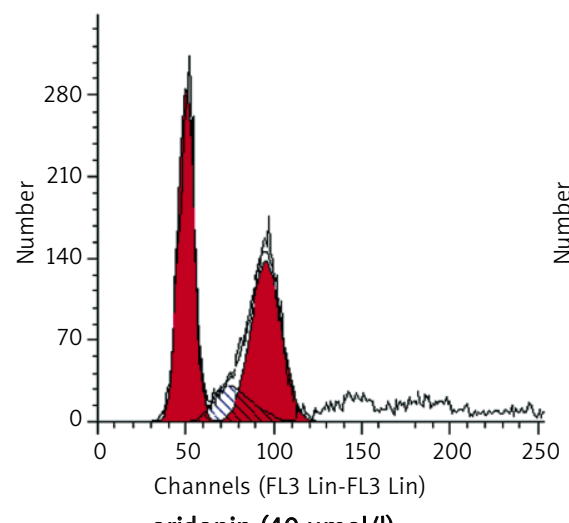

oridonin $(40 \mu \mathrm{mol} / \mathrm{l})$

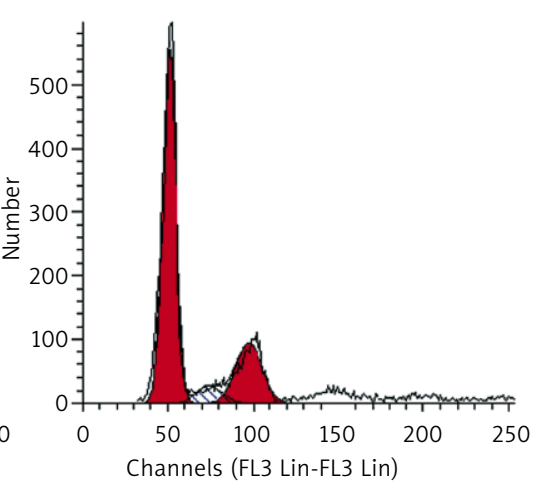

oridonin $(10 \mu \mathrm{mol} / \mathrm{l})$

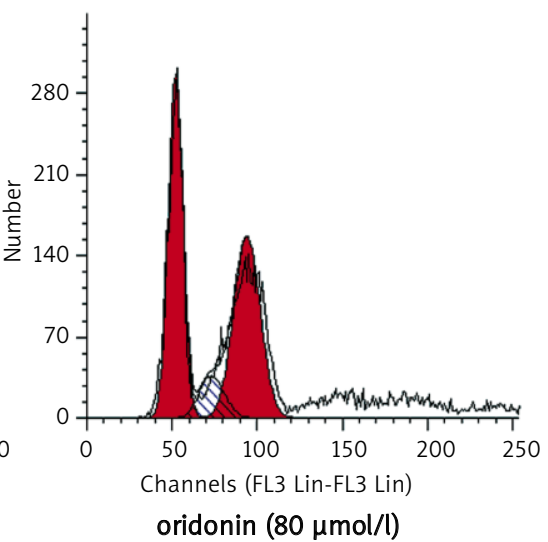

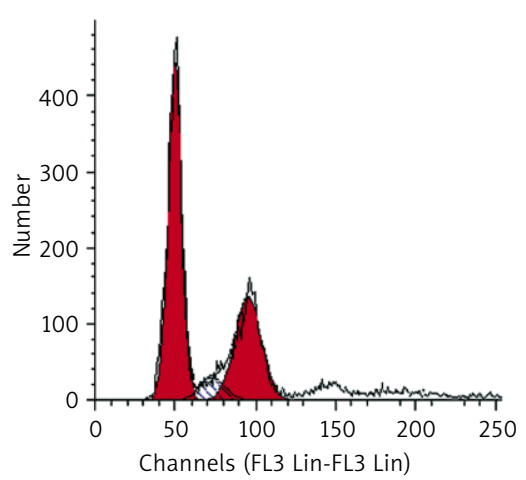

oridonin $(20 \mu \mathrm{mol} / \mathrm{l})$

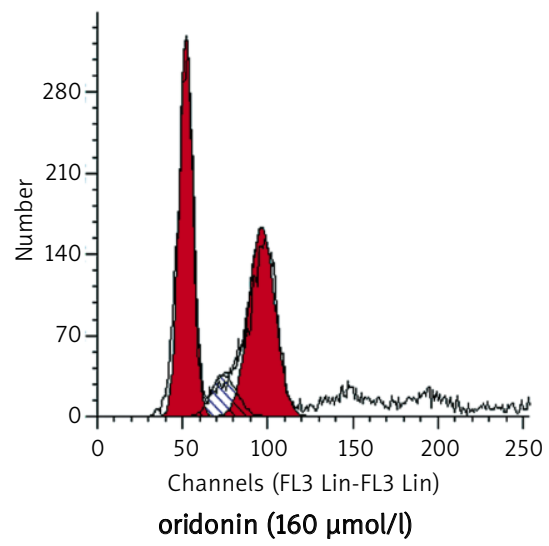

Fig. 3. Effects of oridonin on cell cycle distribution in cultured MCF-7 cells. Flow cytometric analysis of the DNA content in control and oridonin-treated groups $(10,20,40,80$ and $160 \mu \mathrm{mol} / \mathrm{l})$ for $48 \mathrm{~h}$

\section{Effect of oridonin on cell cycle distribution}

To determine whether oridonin regulates the cell cycle, the distribution of MCF-7 cells in various compartments of the cell cycle was analyzed by flow cytometry after oridonin treatment for $48 \mathrm{~h}$. The percentage of cells in each phase of the cell cycle in control and treated groups is summarized in Fig. 3 and Table 3. Compared with the control, an accumulation of MCF-7 cells in the G2/M phase was noted in the treatment group with various oridonin concentrations.

Effect of oridonin on the formation of ATM S1981 phosphorylation and $\gamma \mathrm{H} 2 \mathrm{AX}$ nuclear foci in MCF-7 cells

To explore the G2/M arrest induced by oridonin, we observed co-localization between phosphor-S1981 ATM foci and those of $\gamma \mathrm{H} 2 \mathrm{AX}$ foci in MCF-7 cells treated with oridonin. Furthermore, a higher number of Ctrl MCF-7 cells exhibited $\gamma \mathrm{H} 2 \mathrm{AX}$ nuclear foci when treated with increasing doses of oridonin (Fig. 4).

Effects of oridonin on the protein expression of P-ATM, P-CHK2, $\gamma \mathrm{H} 2 \mathrm{AX}$ and P-P53

To further investigate the molecular mechanisms underlying oridonin inhibition of cell growth and induction of DNA damage, we examined the expression of P-ATM, P-CHK2, $\gamma \mathrm{H} 2 \mathrm{AX}$ and P-P53 in MCF-7 cells. Immunoblotting analysis revealed that the expression of these proteins was
Table 3. Effects of oridonin on cell cycle analysis

\begin{tabular}{lccc} 
Groups & GO/G1(\%) & $\mathrm{S}(\%)$ & $\mathrm{G} 2 / \mathrm{M}(\%)$ \\
\hline control & 67.43 & 16.32 & 16.25 \\
\hline oridonin $(10 \mu \mathrm{mol} / \mathrm{l})$ & 64.32 & 13.95 & 21.73 \\
\hline oridonin $(20 \mu \mathrm{mol} / \mathrm{l})$ & 61.73 & 8.62 & $29.65^{*}$ \\
\hline oridonin $(40 \mu \mathrm{mol} / \mathrm{l})$ & 50.65 & 8.5 & $40.85^{\star *}$ \\
\hline oridonin $(80 \mu \mathrm{mol} / \mathrm{l})$ & 32.65 & 13.57 & $53.78^{\star *}$ \\
\hline oridonin $(160 \mu \mathrm{mol} / \mathrm{l})$ & 28.11 & 9.72 & $62.17^{\text {** }}$
\end{tabular}

Analysis of DNA in MCF-7 cells. The percentage of each cell cycle was determined by flow cytometry. Compared with the control, oridonin could induce G2/M arrest in MCF-7 cells. ${ }^{*} p<0.05,{ }^{* *} p<0.01$, compared with control

increased in oridonin treatment cells in a dose-dependent manner (Fig. 5).

\section{Discussion}

In the present study, we found that oridonin can inhibit the growth of human breast cancer MCF-7 cells, which was consistent with the previous study. We further investigated the mechanism of how oridonin inhibits cell growth, and found that oridonin treatment not only induced G2/M arrest in MCF-7 cells, but also caused significant DNA damage, shown in the comet assay.

The DNA damage checkpoints are biochemical pathways that delay or arrest cell cycle progression in response to genomic DNA damage. In response to DNA damage, cells 


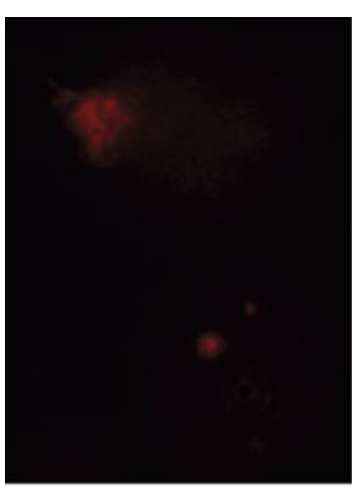

PBS-P-ATM

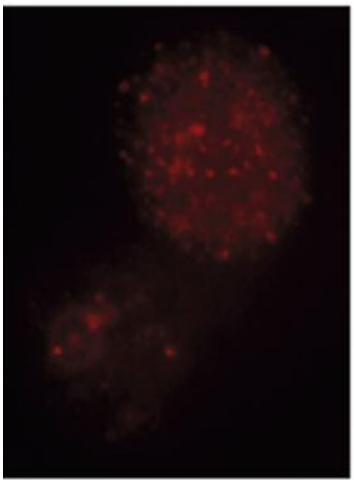

P-ATM

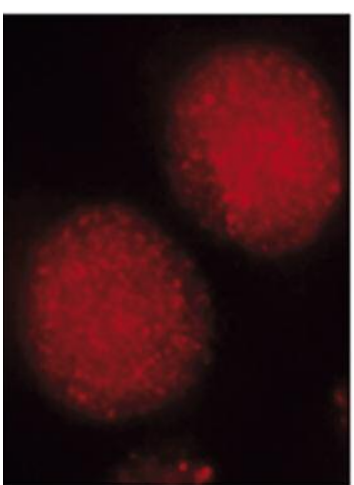

P-ATM

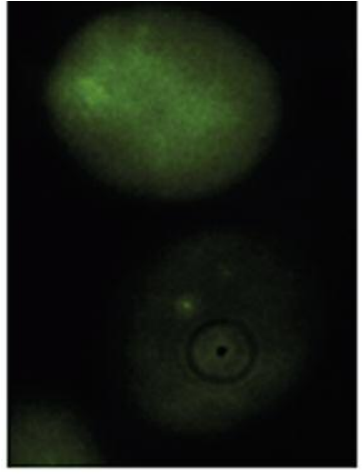

PBS- $\gamma \mathrm{H} 2 \mathrm{AX}$

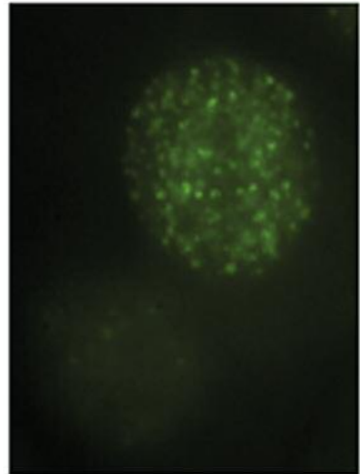

$\gamma \mathrm{H} 2 \mathrm{AX}$

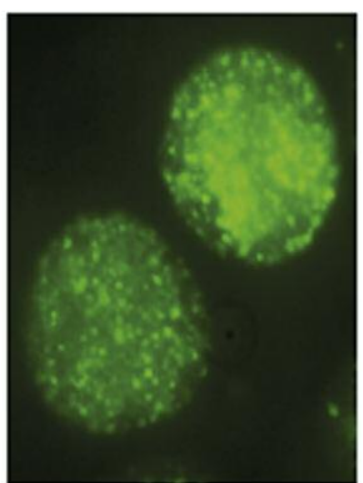

$\gamma \mathrm{H} 2 \mathrm{AX}$

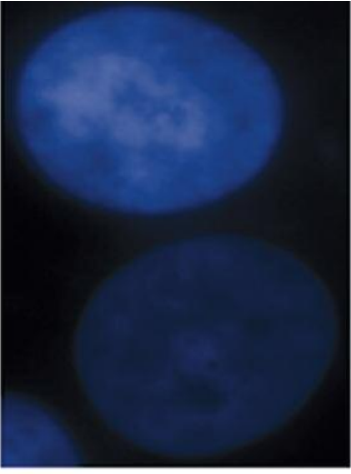

PBS-control

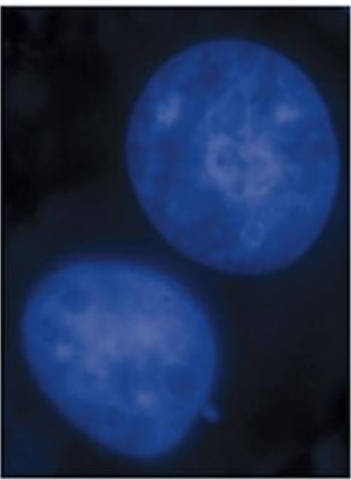

DAPI

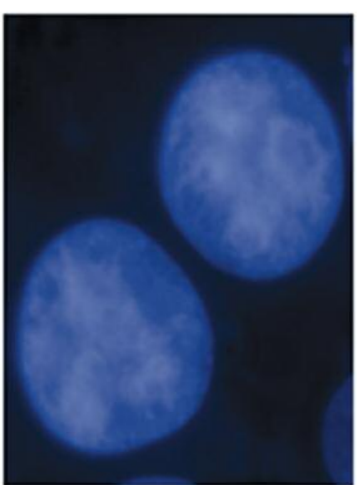

DAPI

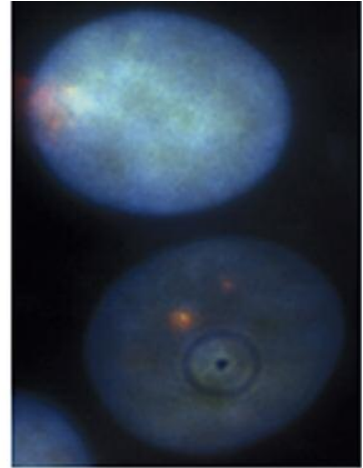

PBS-merge

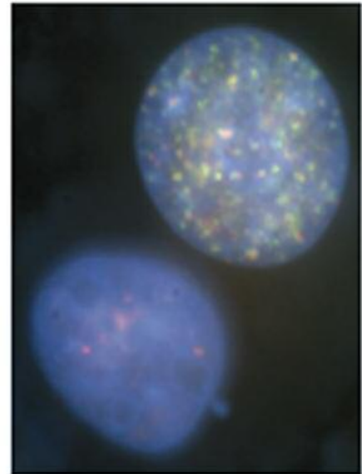

Merge

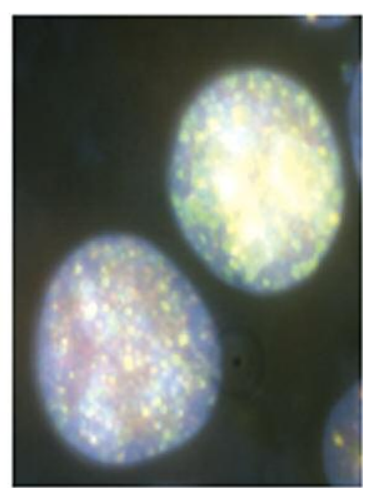

Merge

Fig. 4. Formation of ATM S1981 phosphorylation and $\gamma \mathrm{H} 2 \mathrm{AX}$ nuclear foci in oridonin-treated MCF-7 cells. MCF-7 cells were treated with oridonin for $8 \mathrm{~h}$, followed by double immunofluorescent staining for ATM S1981 phosphorylation (red) and $\gamma \mathrm{H} 2 \mathrm{AX}$ (green). Nuclei were counter-stained with DAPI (blue). At least 200 cells in four randomly selected fields were counted to determine the percentage of cells positive for active ATM or $\gamma \mathrm{H} 2 \mathrm{AX}$ nuclear foci. Experiments were repeated three times

would activate ataxia-telangiectasia mutated (ATM), one of the sensor kinases, which in turn phosphorylates multiple downstream substrates, including the effector kinase CHK2 [14], resulting in cell-cycle checkpoint initiation and/or apoptosis. In our study, we found that oridonin treatment not only induced G2/M arrest in MCF-7 cells, but also caused significant DNA damage, shown in the comet assay. A number of studies have revealed that different molecular mechanisms correspond to DNA damage checkpoints at different phases [15], and ATM/CHK2 signaling pathways especially play important roles [16]. Markers of a constitutively active DNA damage response have been described in many types of malignant lesions in different tissues [17]. Therefore, the major kinases of the signaling pathways in MCF-7 cells treated by oridonin were analyzed. Tumor suppressor p53 participates in multiple cellular activities including the cell-cycle checkpoints and DNA repair, playing a critical role in maintaining genome integrity and stability [18]. P53 can also trigger cell apoptosis, which is associated with treatment failure in childhood acute lymphoblastic leukemia [19]. However, more than half of human tumors display p53 mutation or deficiency. Therefore, the DNA damage checkpoints in tumor cells may be different from those 


\section{A}

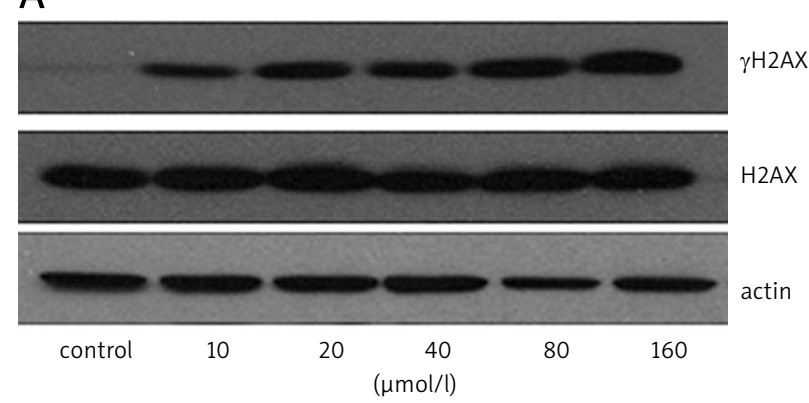

C

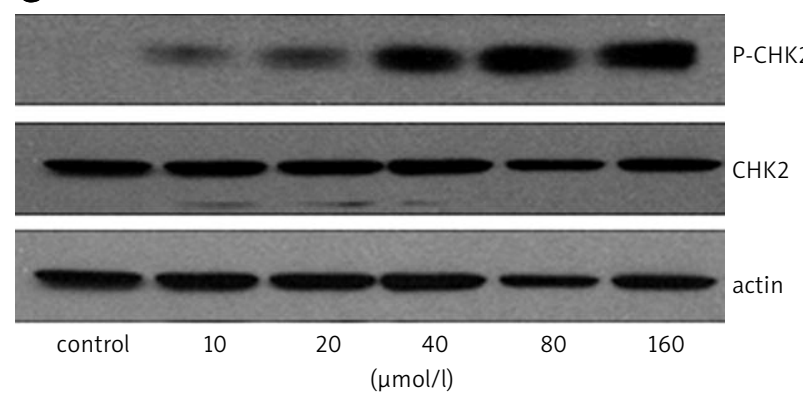

B

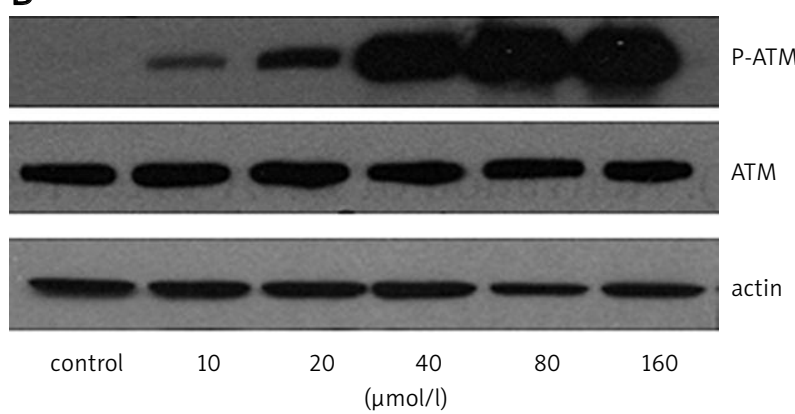

D

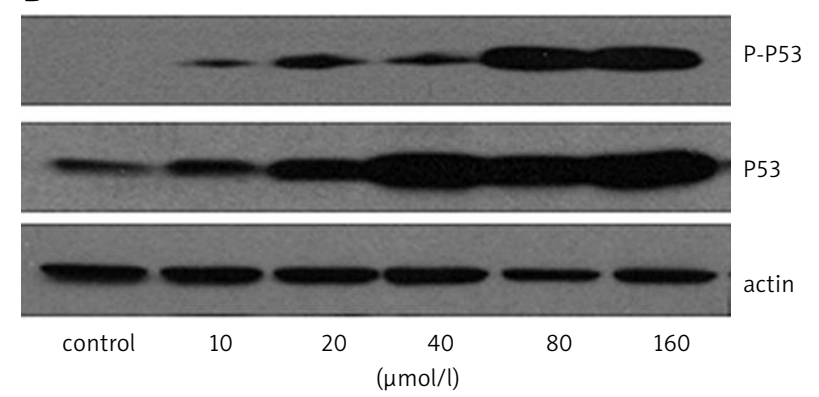

Fig. 5. Western blotting analysis of expression of $\gamma \mathrm{H} 2 \mathrm{AX}$ (A), P-ATM (B), P-CHK2 (C), and P-P53 (D) protein. The MCF-7 cells were treated with different concentrations of oridonin. Total cellular proteins were harvested and subjected to Western blotting analysis. $\beta$-actin was used as a loading control

in normal tissues. Study of the DNA damage checkpoints in tumor cells will not only help us to understand the regulatory mechanisms of a cell cycle, but also provide a potential theory for developing new tumor therapy.

In vertebrates, ATM and ATM- and Rad3-related (ATR), members of the phosphatidylinositol 3-kinase related protein family, are critical checkpoint regulators which work upstream of the DNA damage response pathway [20]. The checkpoint functions of ATR and ATM are mediated in part by a pair of checkpoint effector kinases termed CHK1 and CHK2 [21]. The histone H2AX is one of the targets for ATMmediated phosphorylation [22]. Phosphorylated H2AX $(\gamma-\mathrm{H} 2 \mathrm{AX})$ was the gold standard for early detection of DNA damage. These molecules participate in the transmission of DNA damage signals to downstream molecules such as CHK2 to foci containing the site of damaged DNA. To consolidate the ATM activation, we demonstrated that oridonin clearly induced the nuclear foci of S1981-phosphorylated (phosphorS1981) ATM in MCF-7 cells.

P53 is a tumor suppressor mainly involved in the transcriptional regulation of a large number of growth-arrest and apoptosis-related genes [23]. Upon genotoxic damage, p53 contributes to cell-cycle arrest at the G1/S and/or G2/M checkpoints through diverse mechanisms [24]. When analyzing the DNA damage signaling pathway induced by oridonin, for the first time, we found that treatment with oridonin induced G2/M arrest and DNA damage signaling involving $\gamma$ - $\mathrm{H} 2 \mathrm{AX}$ foci formation and CHK2 phosphorylation. The DNA damage signaling induced by oridonin was also mediated by ATM and the downstream signaling of ATM, which is involved in the phosphorylation of CHK2. It strongly suggests that ATM is necessary for this signaling pathway. Furthermore, the protein expression level of P-P53 increased significantly in a dose-dependent manner. In summary, the role of the ATM/CHK2/p53 pathway in MCF-7 cell suppression can be attributed to its influence on the induction of apoptosis as well as on the regulation of DNA damage dependent checkpoints.

In conclusion, oridonin may be a potentially promising agent of natural resource to treat breast cancer. DNA damage provoked p53-mediated G2/M cell cycle arrest in oridonininduced MCF-7 cells. The mechanism was related to activation of the protein kinase ATM, which subsequently activated CHK2, leading to G2/M arrest.

The authors declare no conflict of interest.

\section{References}

1. Perera NM, Gui GP. Multi-ethnic differences in breast cancer: current concepts and future directions. Int J Cancer 2003; 106: 463-7.

2. Schwartsmann G, Ratain MJ, Cragg GM, et al. Anticancer drug discovery and development throughout the world. I Clin Oncol 2002; 20 (18 Suppl): 47S-59S.

3. Wang H, Ye Y, Chui JH, Zhu GY, Li YW, Fong DW, Yu ZL Oridonin induces G2/M cell cycle arrest and apoptosis through MAPK and p53 signaling pathways in HepG2 cells. Oncol Rep 2010; 24: 647-51.

4. Liu YQ, You S, Tashiro S, Onodera S, Ikejima T. Activation of phosphoinositide 3-kinase, protein kinase C, and extracellular signalregulated kinase is required for oridonin-enhanced phagocytosis of apoptotic bodies in human macrophage-like U937 cells. J Pharmacol Sci 2005; 98: 361-71.

5. Bai N, He K, Zhou Z, et al. Ent-kaurane diterpenoids from Rabdosia rubescens and their cytotoxic effects on human cancer cell lines. Planta Med 2010; 76: 140-5.

6. Hsieh TC, Wijeratne EK, Liang JY, Gunatilaka AL, Wu JM. Differential control of growth, cell cycle progression, and expression of NF-kap- 
paB in human breast cancer cells MCF-7, MCF-10A, and MDA-MB231 by ponicidin and oridonin, diterpenoids from the chinese herb Rabdosia rubescens. Biochem Biophys Res Commun 2005; 337: 224-31.

7. Ciciarello M, Mangiacasale R, Casenghi M, Zaira Limongi M, D'Angelo M, Soddu S, Lavia P, Cundari E. p53 displacement from centrosomes and p53-mediated G1 arrest following transient inhibition of the mitotic spindle. J Biol Chem 2001; 276: 19205-13.

8. Redon C, Pilch D, Rogakou E, Sedelnikova O, Newrock K, Bonner W. Histone H2A variants H2AX and H2AZ. Curr Opin Genet Dev 2002; 12: 162-9.

9. Fernandez-Capetillo O, Chen HT, Celeste A, et al. DNA damage-induced G2-M checkpoint activation by histone H2AX and 53BP1. Nat Cell Biol 2002; 4: 993-7.

10. Celeste A, Difilippantonio S, Difilippantonio MJ, et al. H2AX haploinsufficiency modifies genomic stability and tumor susceptibility. Cell 2003; 114: 371-83.

11. Abraham RT. Cell cycle checkpoint signaling through the ATM and ATR kinases. Genes Dev 2001; 15: 2177-96.

12. Peng CY, Graves PR, Thoma RS, Wu Z, Shaw AS, Piwnica-Worms H. Mitotic and $\mathrm{G} 2$ checkpoint control: regulation of 14-3-3 protein binding by phosphorylation of Cdc25C on serine-216. Science 1997; 277: 1501-5.

13. Wu H, Guo H, Zhao R. Effect of Lycium barbarum polysaccharide on the improvement of antioxidant ability and DNA damage in NIDDM rats. Yakugaku Zasshi 2006; 126: 365-71.

14. Stracker TH, Usui T, Petrini JH. Taking the time to make important decisions: the checkpoint effector kinases Chk1 and Chk2 and the DNA damage response. DNA Repair (Amst) 2009; 8: 1047-54.

15. Sancar A, Lindsey-Boltz LA, Unsal-Kaçmaz K, Linn S. Molecular mechanisms of mammalian DNA repair and the DNA damage checkpoints. Annu Rev Biochem 2004; 73: 39-85.

16. Reinhardt HC, Yaffe MB. Kinases that control the cell cycle in response to DNA damage: Chk1, Chk2, and MK2. Curr Opin Cell Biol 2009; 21: 245-55.

17. Bartkova J, Horejsí Z, Koed K, et al. DNA damage response as a candidate anti-cancer barrier in early human tumorigenesis. Nature 2005; 434: 864-70.

18. Bucher N, Britten CD. G2 checkpoint abrogation and checkpoint kinase-1 targeting in the treatment of cancer. Br J Cancer 2008; 98: 523-8.

19. Ociepa T, Maloney E, Kamieńska E, et al. Simultaneous assessment of p53 and MDM2 expression in leukemic cells in response to initial prednisone therapy in children with acute lymphoblastic leukemia. Pol J Pathol 2010; 61: 199-205.

20. Shiloh Y. ATM and related protein kinases: safeguarding genome integrity. Nat Rev Cancer 2003; 3: 155-68.

21. Liu Q, Guntuku S, Cui XS, et al. Chk1 is an essential kinase that is regulated by Atr and required for the G(2)/M DNA damage checkpoint. Genes Dev 2000; 14: 1448-59.

22. Fernandez-Capetillo O, Chen HT, Celeste A, et al. DNA damage-induced G2-M checkpoint activation by histone H2AX and 53BP1. Nat Cell Biol 2002; 4: 993-7.

23. Levine AJ. p53, the cellular gatekeeper for growth and division. Cell 1997: 88: 323-31.

24. Wahl GM, Carr AM. The evolution of diverse biological responses to DNA damage: insights from yeast and p53. Nat Cell Biol 2001; 3: E277-86.

\section{Address for correspondence}

Yan Tan

Central Research Laboratory

The First Affiliated Hospital of Jilin University

Changchun, 130021, P. R. China

tel./fax: +863358074662

e-mail: tanyanjida@163.com

Submitted: $\quad$ 19.06.2012

Accepted: $\quad 31.08 .2012$ 